DOI: $10.31471 / 2311-1399-2019-1(11)-7-13$

\title{
Simulation of chemical and technological processes of a hydrocarbon preparation plant
}

\author{
O.O. Liaposhchenko ${ }^{1}$, V.F. Moiseev ${ }^{2}$, V.M. Marenok ${ }^{1}$, O.M. Khukhryanskyy ${ }^{3}$, \\ O.Ye. Starynskyy*1, V.V. Kovtun ${ }^{1}$ \\ ${ }^{1}$ Sumy State University; \\ 2, Rymskogo-Korsakova Str., Sumy, 40007, Ukraine \\ ${ }^{2}$ National Technical University «Kharkiv Polytechnic Institute»; \\ 2, Kyrpychova Str., Kharkiv, 61002, Ukraine \\ ${ }^{3}$ Private JSC " UKRHIMPROEKT”; \\ 13, Illinska St., Sumy, 40009, Ukraine
}

Received: 03.06.2019 Accepted: 13.06.2019

\begin{abstract}
This article presents a low-tonnage oil and gas processing plant (OGPP-20), its main process equipment and the operating principle. Three methods for producing a liquefied propane-butane fraction and designs of the equipment for its implementing are proposed: compression and condensation, compression and further throttling which allows the compressed gas cool to lower temperatures and rectification. The results of numerical studies of the methods of producing liquefied propane-butane in the Aspen HYSYS program for the thermodynamic model of Peng-Robinson substantiate the method of obtaining the liquefied propane-butane fraction and its design.
\end{abstract}

Keywords: computer simulation, low-tonnage, propane-butane, separator, throttle effect.

Unlike large oil refinery plants that target specific raw material stock, mini-refineries can be used to process unstable hydrocarbon raw material. Therefore, mini-refineries are often supplied with unstable oil or gas condensate. In its processing, the lightest fraction is hydrocarbon gas. Mass gas consumption is $5 \%$ of the raw material. Capture of a gas stream containing valuable hydrocarbon components (propane and butane) is perspective in terms of its further processing and, consequently, an increase in the rate of utilization of Ukraine's energy resources. Therefore, current units' layouts must be subject to upgrading and modernization. The paper deals with a low-tonnage oil and gas processing plant (OGPP-20), the layout of which is presented in Figure 1.

The plant works as follows: first, the dehydrated oil enters the raw material tank (VC), from where with the help of pumps $\left(\mathrm{P}_{1}\right)$ it is sent to heat exchangers $\left(\mathrm{HE}_{1-3}\right)$, then the heated flow turns in turn to separate parts of the tubular heater $(\mathrm{H})$. In the tubular heater, the raw material is heated to the boiling point, and in this state it is fed under the lower plate of the distillation column (C). The reflux stream is fed into the upper part

* Corresponding author:

info@sumdu.eduv.ua

(C) 2019, Ivano-Frankivsk National Technical University of Oil and Gas.

All rights reserved. of the column. The upper product of the column (C) is a light fraction removed from the column at a temperature of $150{ }^{\circ} \mathrm{C}$ and fed to the air-cooling apparatus $\left(\mathrm{C}_{1}\right)$, where the vapors partially condense. The gas-liquid stream enters the separator (VP). Part of the resulting fluid is returned to the column for irrigation. Target fractions are discharged along the height of the column by lateral shoulder straps. The first side fraction is a fraction of $150-200{ }^{\circ} \mathrm{C}$, the second side fraction is a fraction of $200-350{ }^{\circ} \mathrm{C}$. The bottom residue of the column (C) is fuel oil, which is discharged through the lower fitting and sent to the block of heat exchangers $\left(\mathrm{HE}_{1-3}\right)$.

As a result of the processing of unstable oil or gas condensate, hydrocarbon gas is formed. As the initial raw material passes through the tank (VC), it also begins to actively release the gas fraction. These two streams, the hydrocarbon gas and the gas fraction from the tank (VC), must be mixed and further processed to produce liquefied propane-butane. To extricate the $\mathrm{C}_{3+}$ fraction from the gas mixture it is necessary to create conditions under which the transition of hydrocarbons from the gaseous state to the liquid with subsequent separation of the liquid phase will be possible. It is suggested to consider three ways of producing liquefied propane-butane: using separation (Fig. $2 a$ ), using a throttle effect (Fig. $2 b$ ) and using a deethanizer (Fig. $2 c$ ).

The separation process is applied in the following way. By mixing hydrocarbon gases, we obtain a gas stream 1 that is sent to the compressor (C2) for compression. Gas compressed to $1.7 \mathrm{MPa}$ is fed into the 


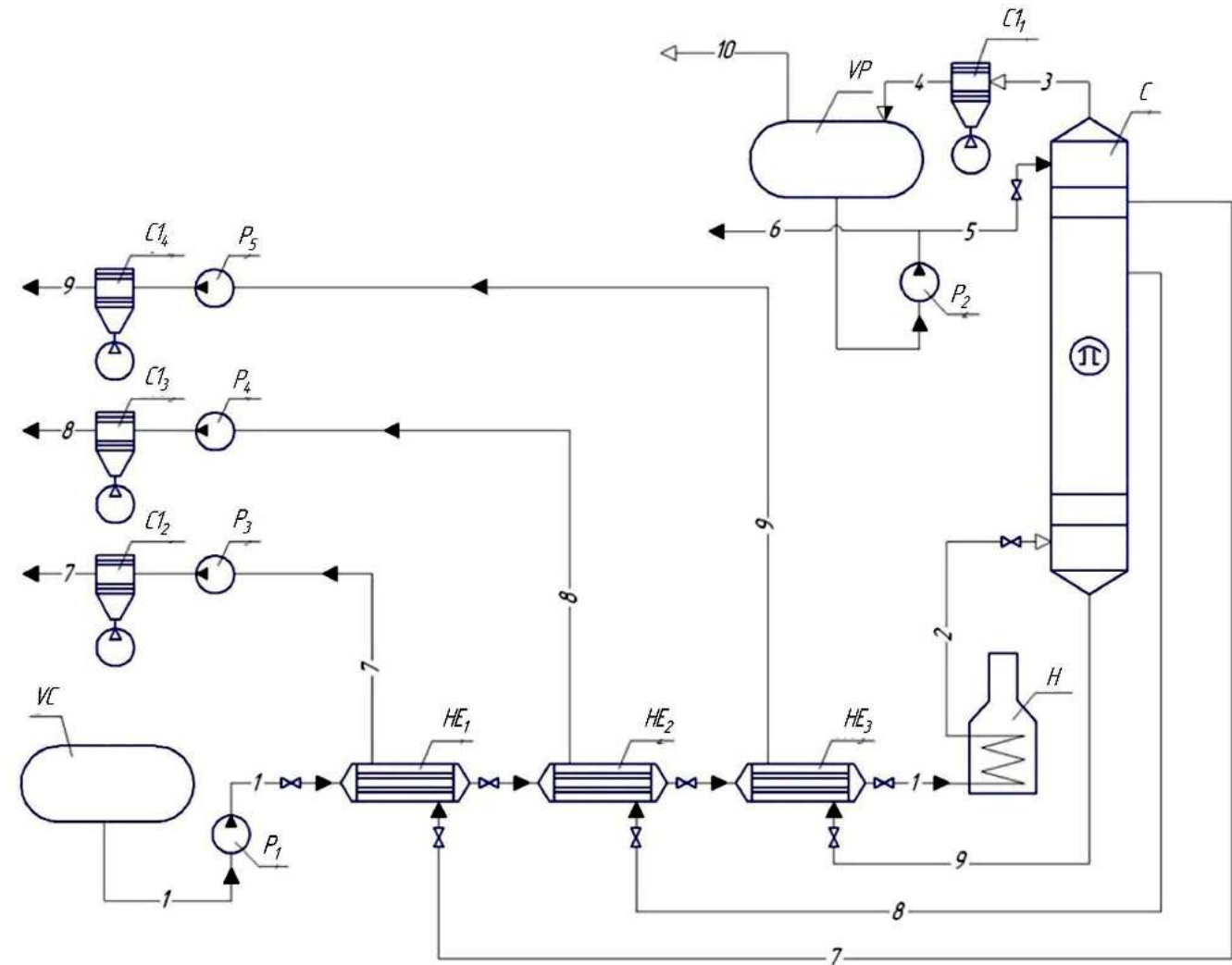

C1 $1_{1 \ldots 4}$-Coolers; $P_{1 \ldots 5}-$ Pumps; HE $E_{1 \ldots 3}-$ Heat Exchangers; H-Heater; C-Column; VC, VP-Vessel;

1 -dehydrated oil; 2 - dehydrated oil, heated to boiling point; 3 - light hydrocarbon fraction;

4 - condensed light hydrocarbon fraction; 5 - reflux; 6 - liquid light hydrocarbon fraction;

7 - fraction $150-200{ }^{\circ} \mathrm{C} ; 8$ - fraction $200-350{ }^{\circ} \mathrm{C}$; 9 - fuel oil; 10 - gas light hydrocarbon fraction

\section{Figure 1- OGPP-20 layout}

heat exchanger (HE) for cooling. After cooling, we obtain a two-phase stream 3 in which lighter hydrocarbons are in a gaseous state. Separation of hydrocarbons from the liquid phase takes place in a vertical separator (S). Methane-ethane fraction 4 is discharged from the upper part of the separator and liquefied propane-butane 5 from the lower part.

The main difference between the second method of producing the propane-butane fraction is the throttling of the compressed gas-liquid stream, which allows to reduce its temperature, with the pressure remaining equal to $1.7 \mathrm{MPa}$. This, in turn, will increase the amount of separated propane-butane fraction.

The third way is to separate the gas-liquid stream and obtain the target component, instead of the separator uses a nozzle (deethanizer), with auxiliary equipment - evaporator and heat exchanger.

Therefore, the purpose of the study is to study the processes of obtaining liquefied propane-butane from unstable hydrocarbons for the selection of optimal equipment for the low-tonnage oil preparation plant.

Due to the complexity and duration of surveys and measurements of the performance of real industrial facilities in research related to the development or improvement of methods of obtaining the finished product, numerical methods and software complexes that implement them are often used [1-3]. Typically, to simulate the modes of technological lines researchers use software systems that allow you to calculate the material and thermal balances of these lines, namely ChemCAD, Aspen HYSYS, MATLAB, Mathcad and others [4-6]. It should be noted that these software complexes can be used both individually and in combination to develop more accurate mathematical models and to process the obtained simulation results [7].

One of the main factors for obtaining reliable simulation results in these software complexes is the choice of thermodynamic models for the calculation of technological processes. To investigate separation and heat transfer processes where hydrocarbon components are present, it is recommended to use UNIFACK-value, Soave-Redlich-Kwong (SRK), Rautenbach model and Peng-Robison models, suitable for the calculation of material and thermal balance, the equilibrium constants of hydrocarbon systems at moderate and high pressure values [8-10].

Thus, the tasks of the work are modeling of chemical and technological processes occurring in the equipment OGPP-20, to substantiate the choice of a suitable hardware design for the method of producing propane-butane fraction.

Aspen HYSYS was selected for the computer simulation of chemical engineering processes and operating modes of the basic equipment of a lowtonnage oil and gas processing plant with a LPG unit. The composition of the mixture containing the gas component is demonstrated in Table 1. 


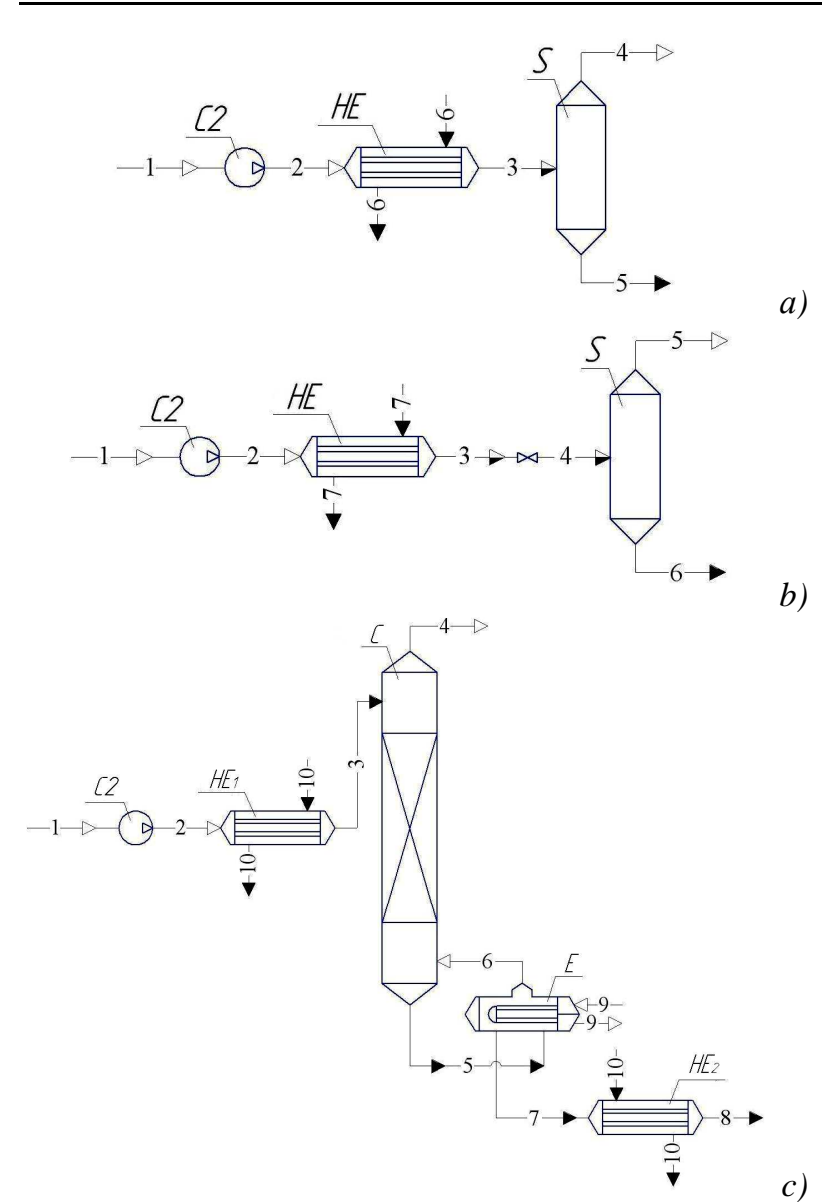

a) using separation; b) using a choke effect; c) using a deethanizer (C2 - Compressor; S-Separator; E-Evaporator; $C$-Deethaniser column)

Figure 2 - LPG unit

First, we define the component composition of the original mixture and the molar fractions of the components shown in Table 1.
We choose the Peng-Robinson thermodynamic model. We specify additional settings, such as:

enthalpy calculation method for equation of state Equation of state;

Peng-Robinson state equation variant - HYSYS; match the equation.

Next we configure the parameters of the original mixture:

data type - TBP;

acceleration conditions at true boiling point ASTM D1160;

viscosity type - Dynamic;

temperature for viscosity $1-37.78{ }^{0} \mathrm{C}$;

viscosity $2-98.89{ }^{\circ} \mathrm{C}$;

Enter the values of temperature and volume fraction of the liquid in accordance with Table 2.

We create an output stream, set the temperature, pressure and flow rate: temperature $40.0{ }^{\circ} \mathrm{C}$, pressure $0.1013 \mathrm{MPa}$, mass flow rate $160.0 \mathrm{~kg} / \mathrm{h}$.

The last step is a technological layout of hydrocarbons prepration plant with a LPG unit. For each method of propane-butane fraction production, a separate technological layout was developed, taking into account the features of the hardware design (Figures 3-5).

The results of computer simulations of a lowtonnage oil and gas processing plant (OGPP-20) with a LPG unit are shown in Table 3. Chemical-technological process simulations were performed for each method of propane-butane manufacturing and with different operating parameters of the hydrocarbon preparation plant equipment.

The paper considered three possible schemes for creating a LPG unit in OGPP-20 plant: with the use of separation; using the throttle effect; with the use of a deethanizer.

The costs of the propane-butane fraction were calculated, taking into account the permissible saturated vapor pressure: with the use of separation $\mathrm{G}=78.8 \mathrm{~kg} / \mathrm{h}$;

Table 1 - Gas mixture composition

\begin{tabular}{|l|c|c|c|}
\hline \multicolumn{1}{|c|}{ Component } & Volume fraction, \% & Mass fraction, \% & Molar fraction, \% \\
\hline Carbon dioxide & 0.998 & 0.998 & 0.984 \\
\hline Methane & 17.642 & 6.422 & 17.312 \\
\hline Ethan & 12.813 & 8.742 & 12.650 \\
\hline Propane & 34.153 & 34.172 & 34.014 \\
\hline$i$ - Butane & 8.281 & 10.921 & 8.353 \\
\hline$n$ - Butane & 13.247 & 17.470 & 13.40 \\
\hline neo- Pentane & 1.183 & 1.938 & 1.216 \\
\hline$i$ - Pentane & 6.609 & 10.820 & 6.793 \\
\hline$n$ - Pentane & 4.284 & 7.013 & 4.439 \\
\hline$n e o$ - Hexane & 0.521 & 0.995 & 0.555 \\
\hline$i$ - Hexane & 0.161 & 0.307 & 0.171 \\
\hline$n$ - Hexane & 0.106 & 0.202 & 0.113 \\
\hline \multicolumn{1}{|c|}{ Total } & $\mathbf{1 0 0}$ & $\mathbf{1 0 0}$ & $\mathbf{1 0 0}$ \\
\hline
\end{tabular}

Table 2 - True boiling point and volume fractions of liquid

\begin{tabular}{|c|c|c|c|c|c|c|c|c|c|c|c|c|c|}
\hline Parameter & $\mathbf{t}_{\mathbf{0}}$ & $\mathbf{t}_{10}$ & $t_{15}$ & $t_{20}$ & $t_{25}$ & $t_{30}$ & $t_{35}$ & $t_{40}$ & \multirow{3}{*}{$\begin{array}{c}\text { Absorbent of } \\
\text { diesel fuel }\end{array}$} & $t_{10}$ & $\mathbf{t}_{15}$ & $\mathbf{t}_{20}$ & $t_{25}$ \\
\hline Temperature & 43 & 73 & 85 & 95 & 105 & 115 & 136 & 150 & & 206 & 232 & 265 & 297 \\
\hline Volume fraction & 0.0 & 10.0 & 15.0 & 20.0 & 25.0 & 30.0 & 35.0 & 40.0 & & 50.0 & 55.0 & 60.0 & 65.0 \\
\hline
\end{tabular}




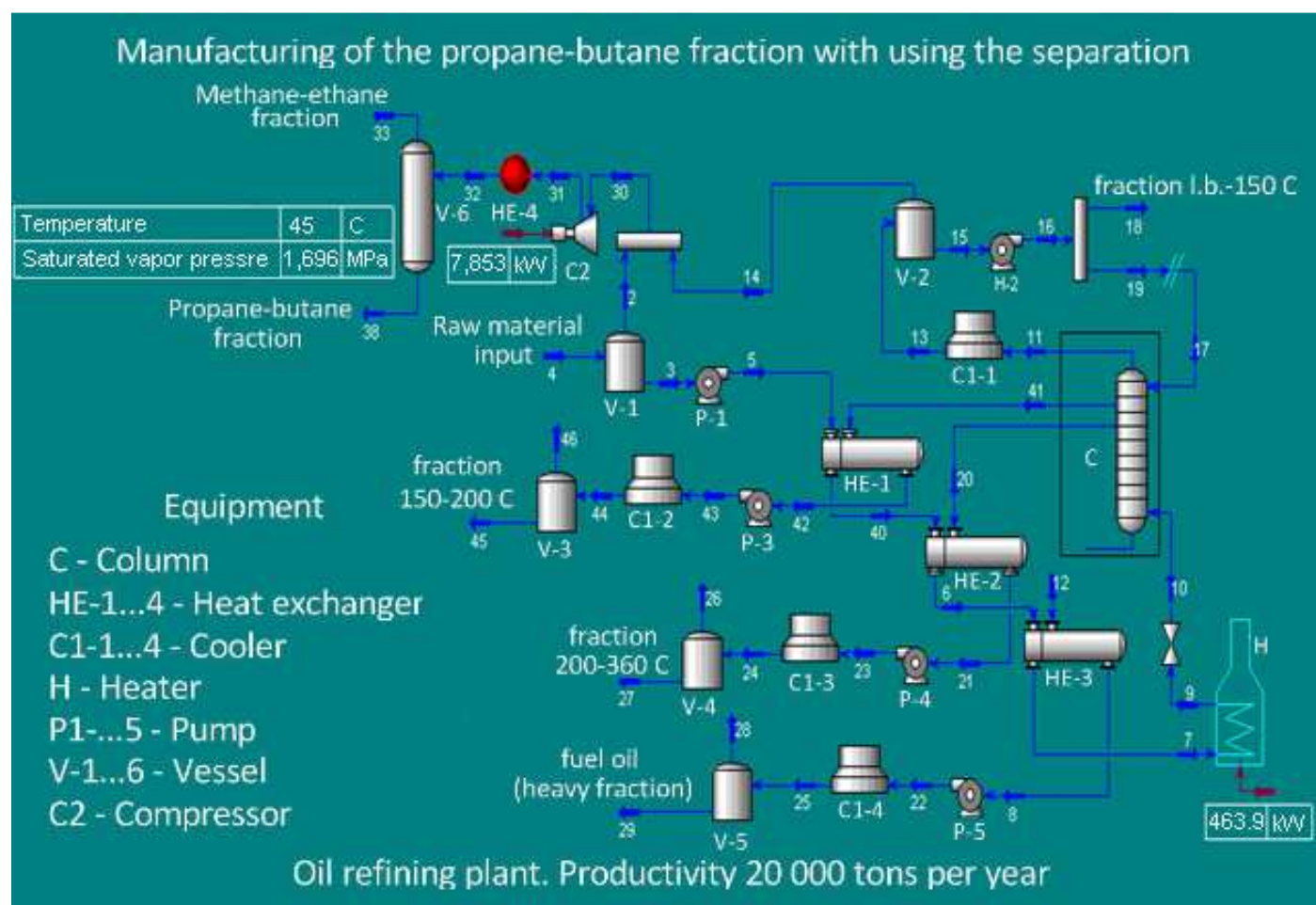

Figure 3 - Manufacturing of liquefied propane-butane fraction, using separation method

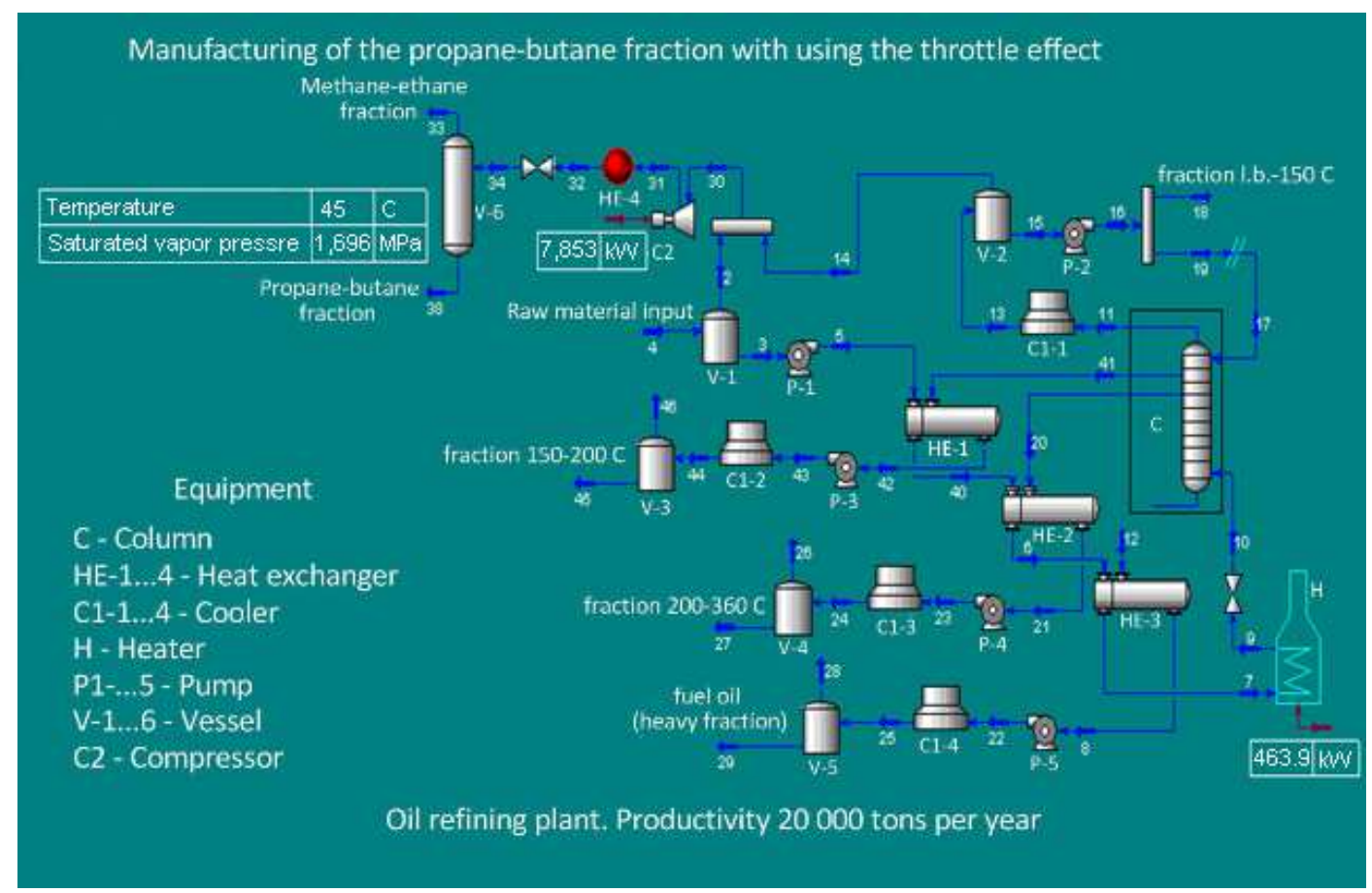

Figure 4 -Manufacturing of liquefied propane-butane fraction, using the throttle effect

using the throttle effect $\mathrm{G}=78.4 \mathrm{~kg} / \mathrm{h}$; using a deethanizer $\mathrm{G}=104.0 \mathrm{~kg} / \mathrm{h}$. The first two installation options give almost identical values of the mass flow rate of propane-butane. As for the hardware design, it is also practically the same. The third option (with the use of deethanizer) allows to obtain more liquefied propanebutane (approximately by $25 \mathrm{~kg} / \mathrm{h}$ (600 kg per day)). But this process is more energy consuming and the distillation column is more complex than the separator.

Thus, on the basis of the analysis of calculations of material and energy balances of installations, as well as the complexity of the development and operation of technological equipment, the optimal equipment for the method of manufacturing propane-butane fraction is a unit with the use of a deethanizer.

In future studies, it is planned to carry out computer simulations of the chemical and technological processes occurring in the equipment of the gas condensate processing plant (Fig. 6) to determine the optimal operating parameters for determining possible ways to improve the efficiency and intensity of the separation and heat transfer processes. 


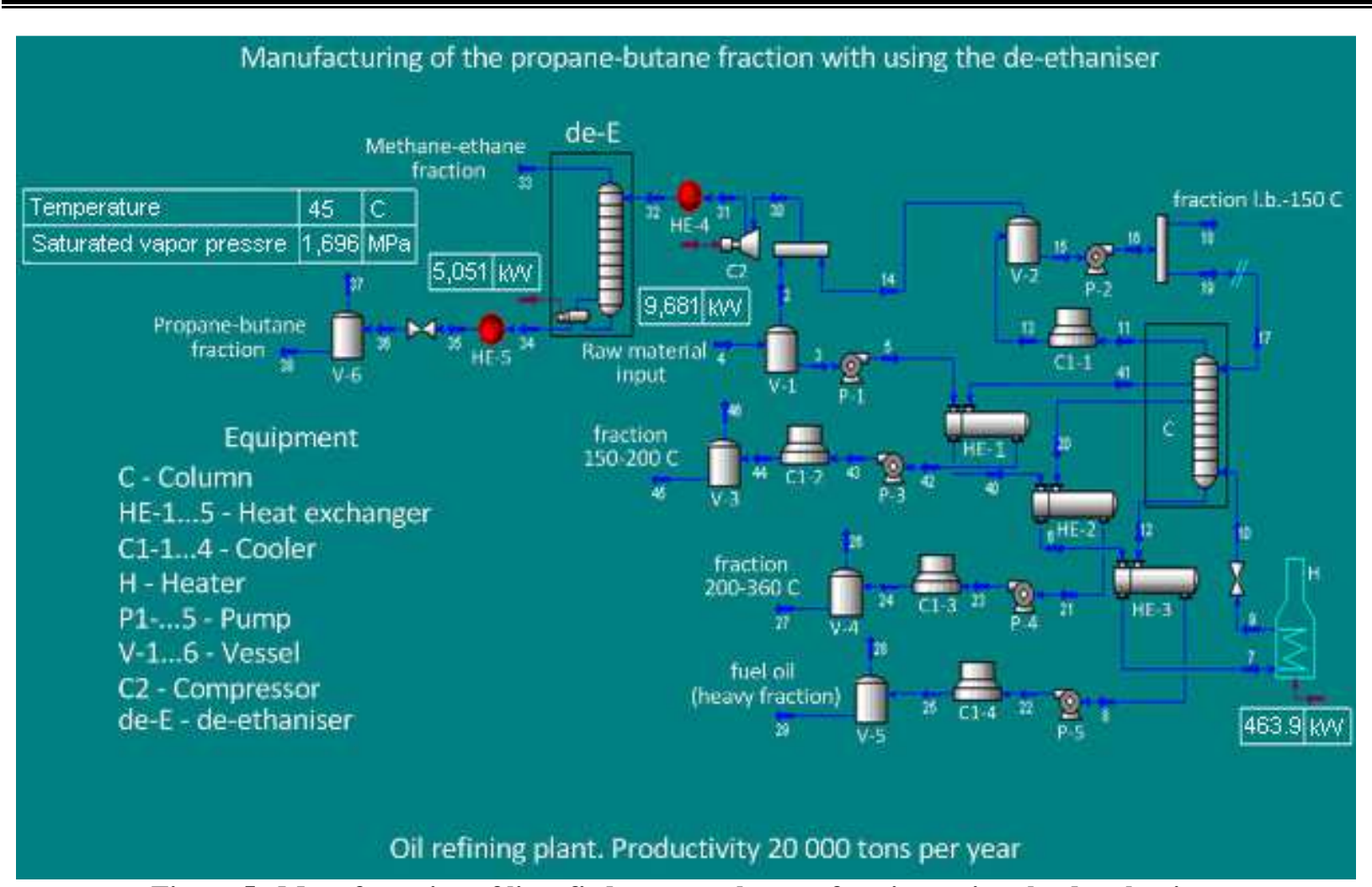

Figure 5 -Manufacturing of liquefied propane-butane fraction, using the de-ethanizer

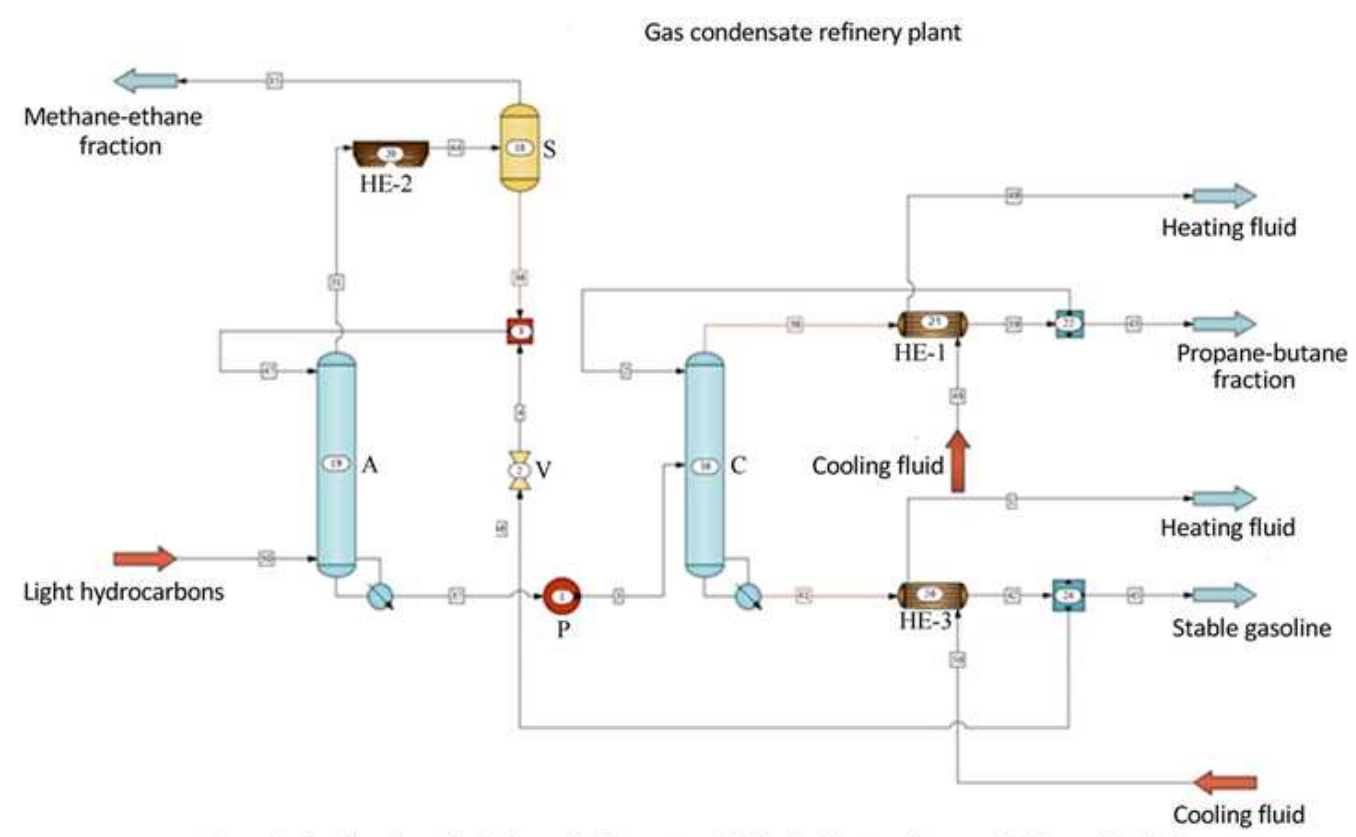

Legend: A - Absorber, C - Column, S - Separator, HE-1...3 - Heat exchanger, P - Pump, V - Valve

Figure 6 - Gas condensate processing plant layout

The work was carried out with the support of the Ministry of Education and Science of Ukraine (State Reg. No 0117U003931 "Development and implementation of energy efficient modular separation devices for oil and gas and purification equipment") under the supervision of Dr. Liaposhchenko O.O.

\section{References}

[1] Pankrushina, AV \& Gartman, TN 2017, 'Process design of complex systems of rectification columns and the evaluation of their effectiveness with the assumption of the range of feed composition', Theor Found Chem Eng, 51:858866. https://doi.org/10.1134/s0040579517050177.

[2] Meiri, N, Radus, R \& Herskowitz, M 2017, 'Simulation of novel process of $\mathrm{CO}_{2}$ conversion to liquid $\begin{array}{lllll}\text { fuels', } & J & \mathrm{CO}_{2} & \text { Util, } & \text { 17:284-289. }\end{array}$ https://doi.org/10.1016/j.jcou.2016.12.008.

[3] Valentínyi, N \& Mizsey, P 2014, 'Comparison of pervaporation models with simulation of hybrid separation processes', Period Polytech Chem Eng, 58:7-14. https://doi.org/10.3311/PPch.7120.

[4] Abdelaziz, OY, Hosny, WM, Gadalla MA, et all 2017, 'Novel process technologies for conversion of carbon 
Table 3 - Technical parameters of LPG units

\begin{tabular}{|c|c|c|c|}
\hline \multicolumn{4}{|l|}{ using separation } \\
\hline $\begin{array}{l}\text { K100 compressor } \\
\text { injection pressure, } \mathrm{MPa} \\
\text { power, } \mathrm{kW}\end{array}$ & $\begin{array}{c}1.7 \\
7.85\end{array}$ & $\begin{array}{c}1.7 \\
7.85\end{array}$ & $\begin{array}{c}1.7 \\
7.85\end{array}$ \\
\hline $\begin{array}{l}\text { AT4 heat exchanger } \\
\text { initial temperature, }{ }^{0} \mathrm{C} \\
\text { final temperature, }{ }^{0} \mathrm{C} \\
\text { thermal load, } \mathrm{kW}\end{array}$ & $\begin{array}{c}158 \\
45 \\
15.46\end{array}$ & $\begin{array}{c}158 \\
30 \\
17.96\end{array}$ & $\begin{array}{c}158 \\
25 \\
18.74\end{array}$ \\
\hline Consumption of propane-butane fraction, $\mathrm{kg} / \mathrm{h}$ & 78.8 & 93.3 & 97.4 \\
\hline Saturated vapor pressure of the propane-butane fraction, MPa & 1.69 & 2.05 & 2.185 \\
\hline $\begin{array}{l}\text { Saturated vapor pressure of the propane-butane fraction according } \\
\text { to GOST 20448-90 at a temperature of } 45^{\circ} \mathrm{C}, \mathrm{MPa}\end{array}$ & \multicolumn{3}{|c|}{1.7} \\
\hline \multicolumn{4}{|l|}{ using the throttle effect } \\
\hline $\begin{array}{l}\text { K100 compressor } \\
\text { injection pressure, } \mathrm{MPa} \\
\text { power, } \mathrm{kW}\end{array}$ & $\begin{array}{l}5.0 \\
9.8 \\
\end{array}$ & $\begin{array}{l}5.0 \\
9.8 \\
\end{array}$ & $\begin{array}{l}5.0 \\
9.8 \\
\end{array}$ \\
\hline $\begin{array}{l}\text { AT4 heat exchanger } \\
\text { initial temperature, }{ }^{0} \mathrm{C} \\
\text { final temperature, }{ }^{0} \mathrm{C} \\
\text { thermal load, } \mathrm{kW}\end{array}$ & $\begin{array}{r}198 \\
71 \\
17.32 \\
\end{array}$ & $\begin{array}{c}198 \\
45 \\
20.7 \\
\end{array}$ & $\begin{array}{l}198 \\
25 \\
23 \\
\end{array}$ \\
\hline $\begin{array}{l}\text { Throttle } \\
\text { final pressure, } \mathrm{MPa} \\
\text { temperature after throttle, }{ }^{0} \mathrm{C}\end{array}$ & $\begin{array}{l}1.7 \\
45\end{array}$ & $\begin{array}{l}1.7 \\
24\end{array}$ & $\begin{array}{c}1.7 \\
8\end{array}$ \\
\hline Consumption of propane-butane fraction, $\mathrm{kg} / \mathrm{h}$ & 78.4 & 97.7 & 108.4 \\
\hline Saturated vapor pressure of the propane-butane fraction, MPa & 1.69 & 2.198 & 2.67 \\
\hline $\begin{array}{l}\text { Saturated vapor pressure of the propane-butane fraction according } \\
\text { to GOST 20448-90 at a temperature of } 45^{\circ} \mathrm{C}, \mathrm{MPa}\end{array}$ & \multicolumn{3}{|c|}{1.7} \\
\hline \multicolumn{4}{|l|}{ using the de-ethanizer } \\
\hline $\begin{array}{l}\text { K100 compressor } \\
\text { injection pressure, } \mathrm{MPa} \\
\text { power, } \mathrm{kW}\end{array}$ & $\begin{array}{c}3.0 \\
8.45 \\
\end{array}$ & $\begin{array}{c}3.0 \\
8.45 \\
\end{array}$ & $\begin{array}{c}3.0 \\
8.45 \\
\end{array}$ \\
\hline $\begin{array}{l}\text { AT4 heat exchanger } \\
\text { initial temperature, }{ }^{0} \mathrm{C} \\
\text { final temperature, }{ }^{0} \mathrm{C} \\
\text { thermal load, } \mathrm{kW}\end{array}$ & $\begin{array}{c}174 \\
25 \\
20.8 \\
\end{array}$ & $\begin{array}{c}174 \\
30 \\
20.2 \\
\end{array}$ & $\begin{array}{l}174 \\
45 \\
18 \\
\end{array}$ \\
\hline $\begin{array}{l}\text { De-ethanizer D } \\
\text { op temperature, }{ }^{0} \mathrm{C} \\
\text { bottom temperature, }{ }^{0} \mathrm{C} \\
\text { pressure in the column, } \mathrm{MPa} \\
\text { evaporator load, } \mathrm{kW}\end{array}$ & $\begin{array}{c}24 \\
81.3 \\
2.9 \\
5.05\end{array}$ & $\begin{array}{c}29 \\
81.5 \\
2.9 \\
4.6\end{array}$ & $\begin{array}{c}44 \\
82.2 \\
2.9 \\
3.2 \\
\end{array}$ \\
\hline Consumption of propane-butane fraction, $\mathrm{kg} / \mathrm{h}$ & 104 & 102 & 95.5 \\
\hline Saturated vapor pressure of the propane-butane fraction, MPa & 1.69 & 1.69 & 1.69 \\
\hline $\begin{array}{l}\text { Saturated vapor pressure of the propane-butane fraction according } \\
\text { to GOST } 20448-90 \text { at a temperature of } 45^{\circ} \mathrm{C}, \mathrm{MPa}\end{array}$ & \multicolumn{3}{|c|}{1.7} \\
\hline
\end{tabular}

dioxide from industrial flue gas streams into methanol', $\mathrm{J} \mathrm{CO}_{2}$ Util, 21:52-63. https://doi.org/10.1016/j.jcou.2017.06.018.

[5] Chisalita, DA, Petrescu, L, Cormos, AM \& Cormos, CC 2018, 'Assessing Energy and $\mathrm{CO}_{2}$ Emission Reduction from Ammonia Production by Chemical Looping as Innovative Carbon Capture Technology', Elsevier Masson SAS.

[6] Dibyo, S, Sunaryo, GR, Bakhri, S, et all 2018, 'Analysis on Operating Parameter Design to Steam Methane Reforming in Heat Application', RDE. J Phys Conf, Ser 962. https://doi.org/10.1088/1742-6596/962/1/012052.

[7] Fricke, A \& Schöneberger, JC 2017, 'A Blueprint for

Software Architectures in Process Optimization',

Chemie-Ingenieur-Technik, 89:515-526.

https://doi.org/10.1002/cite.201600130
[8] Haaz, E \& Toth, AJ 2018, 'Methanol dehydration with pervaporation: Experiments and modelling', Sep Purif Technol, 205:121-129.

https://doi.org/10.1016/j.seppur.2018.04.088

[9] Szima, S \& Cormos, CC 2018, 'Improving methanol synthesis from carbon-free $\mathrm{H}_{2}$ and captured $\mathrm{CO}_{2}$ : A technoeconomic and environmental evaluation', $\mathrm{J} \mathrm{CO}_{2}$ Util, 24:555563. https://doi.org/10.1016/j.jcou.2018.02.007.

[10] Al-Mhanna, N 2018, 'Simulation of High Pressure Separator Used in Crude Oil Processing', Processes, 6:219. https://doi.org/10.3390/pr6110219. 
УДК 66.021.1:532.5

\title{
Моделювання хіміко-технологічних процесів в установці підготовки вуглеводнів
}

\author{
О.О. Ляпощенко ${ }^{1}$, В.Ф. Мойсєєв ${ }^{2}$, В.М. Маренок ${ }^{1}$, О.М. Хухрянськийㄱ, \\ О.С. Старинський, В.В. Ковтун \\ ${ }^{1}$ Сумський державний університет; \\ вул. Римського-Корсакова, 2, Суми, 40007, Україна \\ ${ }^{2}$ Національний технічний університет «Харківський політехнічний інститут»; \\ вул. Кирпичова, 2, Харків, 61002, Украӥна \\ ${ }^{3} П р А Т$ “Укрхімпроект”; \\ вул. Ільїнська, 13, Суми, 40009, Україна
}

\begin{abstract}
Описано малотоннажну установку УПН/УПК-20 підготовки вуглеводневої сировини, іiі основне технологічне обладнання та принцип роботи. Запропоновано три способи отримання зрідженої пропанбутанової фракції та їх апаратурне оформлення: компресія та конденсація; компресія, конденсація та подальше дроселювання, що дозволяє охолодити стиснений газ до більш низьких температур; ректифікація. За результатами числових досліджень способів отримання зрідженого пропан-бутану у програмі Aspen HYSYS для термодинамічної моделі Peng-Robinson обгрунтовано спосіб отримання зрідженої пропан-бутанової фракції та його апаратурне оформлення.
\end{abstract}

Ключові слова: дросельний ефект, комп'ютерне моделювання, малотоннажна установка, пропанбутан, сепаратор. 